\title{
Efek Pretreatment Terhadap Pembentukan Lapisan Cake dan Struktur Membrane pada Membran Ultrafiltrasi Aliran Cross-flow dalam Pengolahan Limbah Cair Emulsi Minyak
}

\author{
Suprihanto Notodarmojo ${ }^{1}$, T. Zulkarnain ${ }^{1,2}$, Dini Mayasanthy ${ }^{2} \&$ M. Irsyad $^{1}$ \\ ${ }^{1}$ Departemen Teknik Lingkungan Fakultas Teknik Sipil dan Perencanaan, Institut \\ Teknologi Bandung, Jl. Ganesha No.10, Labtek IXc, Bandung 40132 \\ ${ }^{2}$ Departemen Teknik Kimia, Politeknik Ujungpandang, Sulawesi Selatan
}

Sari. Pengaruh pretreatment terhadap fluks dan pembentukan cake pada penggunaan membran selullosa asetat menggunakan sistem aliran cross-flow telah diteliti. Membran digunakan untuk mengolah limbah cair emulsi minyak yang berasal dari industri automotif pada bagian pemotongan logam. Tujuan dari penelitian adalah untuk melihat pengaruh proses pretreatment terhadap fluks dan fouling yang terjadi, dalam hal ini digunakan pendekatan model pembentukan cake, yang terindikasi melalui nilai konstanta pembentukan cake (k'), dan mempelajari struktur membran. Jenis membran yang digunakan adalah jenis membran hidrofilik selulosa asetat. Operasi membran ultrafiltrasi dua tahap ini menggunakan membran selulosa asetat komposisi $12 \%$ (CA-12) untuk operasi tahap I dan membran selulosa asetat komposisi $15 \%$ (CA-15) untuk operasi tahap II dengan waktu operasi masing-masing 90 menit. Tekanan yang digunakan adalah 3,5 Bar. Dua jenis variasi umpan yang akan diolah membran, yaitu umpan limbah tanpa pretreatment dan umpan limbah dengan pretreatment. Membran setelah beberapa periode beroperasi, maka akan terjadi fouling pada membran yang diikuti dengan terjadinya penurunan fluks permeat. Pada operasi membran tahap I untuk umpan limbah tanpa pretreatment $\mathrm{k}^{\prime}=0,0004 \mathrm{~m}^{2} / \mathrm{L}$ sedangkan untuk umpan limbah dengan pretreatment $\mathrm{k}^{\prime}=0,0001 \mathrm{~m}^{2} / \mathrm{L}$. Pada operasi membran tahap II untuk umpan limbah tanpa pretreatment diperoleh nilai $\mathrm{k}^{\prime}=0,0009 \mathrm{~m}^{2} / \mathrm{L}$ sedangkan untuk umpan limbah dengan pretreatment $\mathrm{k}$ ' $=0,0002 \mathrm{~m}^{2} / \mathrm{L}$. Hasil ini menunjukkan bahwa proses yang menggunakan feeding dengan pretreatment lebih baik dari segi kemungkinan terjadinya fouling bila dibandingkan dengan operasi menggunakan feeding tanpa pretreatment. Analisa struktur membran menggunakan analisa Scanning Electron Microscopy (SEM) dilakukan untuk melihat struktur membran yang belum digunakan dan yang telah digunakan. Hasil SEM menunjukkan bahwa struktur membran adalah asimetrik. Dari hasil SEM terlihat bahwa deposisi kontaminan juga terjadi dalam lapisan dalam membrane (spinger). Selain itu juga terlihat adanya deformasi lapisan spinger. Keunggulan proses membran menggunakan umpan limbah dengan pretreatment disamping dapat meningkatkan fluks permeat, juga dapat menurunkan konstanta pembentukan cake yang berdampak pada meningkatnya waktu operasi membran. 
Kata kunci : Cutting oil; ultra filtrasi; cross-flow, pretreatment; fluks, konstanta pembentukan cake, analisa SEM, deformasi

Effect of pretreatment to the formation of cake layer and membrane structure in the application of ultra filtration cross-flow Membrane for the treatment of oil-water emulsion waste

\begin{abstract}
A study on the effect of pretreatment on the use of cellulose acetate (CA) membrane using cross-flow system to treat oil-water emulsion waste came from metal cutting process of an automotive industry has been done. The objectives of this research are to see the impact of pretreatment process to flux and cake forming, indicated by cake forming constant ( $\left.\mathrm{k}^{\prime}\right)$, and to study membrane structure. The ultra filtration process performance was determined by obtaining the values of permeate flux and rejection. The material of membrane used in this process was cellulose acetate membrane with $12 \%$ of cellulose acetate composition for first stage operation and $15 \%$ for second stage operation. The duration of the process was 90 minutes operation time, by applying operation pressure at 3,5 Bar. There were two types of feeding mode applied, the first was feeding without pretreatment and the second was feeding with pretreatment. After some operation periods, the permeate flux decreases due to fouling. On the first stage of membrane operation, for waste without pretreatment, we obtained the value of $\mathrm{k}^{\prime}=0,0004 \mathrm{~m}^{2} / \mathrm{L}$ and for waste with pretreatment $\mathrm{k}^{\prime}=0,0001 \mathrm{~m}^{2} / \mathrm{L}$. On the second stage membrane operation, for waste without pretreatment the value of $\mathrm{k}^{\prime}=0,0009 \mathrm{~m}^{2} / \mathrm{L}$ and for waste with pretreatment $\mathrm{k}^{\prime}=0,0002 \mathrm{~m}^{2} / \mathrm{L}$. The results mean that pretreatment reduce significantly formation of the cake. It was also obtained that the structure of the membrane is asymmetric. It was shown that deposition of contaminant also occurs within the spinger of the membrane (inner structure of the membrane). Deformation of the membrane spinger was also observed. It is concluded that pretreatment applied to feeding solution increase the running time of the membrane. The benefit of membrane operation used feed with pretreatment, beside increases permeate fluks also decreases the cake forming constant which will longer operation time of membrane.
\end{abstract}

Keywords: Cutting oil; ultra filtration, cross flow, pretreatment, fluks, cake forming constant, SEM analyze, deformation

\title{
$1 \quad$ Pendahuluan
}

Ultrafiltrasi (UF) merupakan proses membran dengan gaya dorong (driving force) tekanan untuk memisahkan partikel, mikroorganisme, molekul-molekul besar (large molecule) dan droplets emulsi. Media penyaringan (filter medium) merupakan membran macropores dengan kemampuan untuk memisahkan partikel yang berukuran antara 0,0001-0,02 $\mu \mathrm{m}$. Membran ini beroperasi pada tekanan antara 1-5 bar dengan batasan permeabilitas adalah 10-60 L/m $\mathrm{m}^{2}$.jam.bar (Mulder, 1996). 
Ultrafiltrasi menjadi teknik pemisahan yang menarik pada pengolahan limbah cair emulsi minyak karena diyakini mudah dalam pengoperasian, dan ekonomis dibandingkan dengan proses pemisahan lainnya seperti sentrifugasi, sedimentasi, filtrasi konvensional. Selain itu pengolahan limbah cair emulsi minyak dengan hanya menggunakan proses konvensional atau secara proses kimia sangat sulit dilakukan karena mengandung konsentrasi suspended solid, COD, kandungan logam dan minyak yang tinggi (Bennet, 1973; Kim et al.,1989). Kadar COD dari limbah emulsi minyak yang umumnya sangat tinggi $(>50000 \mathrm{mg} / \mathrm{L})$, akan menyulitkan proses pengolahan biologis konvensional.

Dalam operasi membran dikenal dua jenis aliran umpan, yaitu aliran cross-flow dan aliran dead-end. Pada sistem cross flow, arah aliran umpan parallel atau sejajar pada permukaan membran. Aliran parallel tersebut akan menghasilkan gaya geser (shear forces) dan/atau turbulensi didekat permukaan membran sehingga pembentukan filter cake (deposisi partikel yang menumpuk pada permukaan membran) relatif kecil. Pada aliran dead end, keseluruhan dari fluida melewati membran (sebagai media filter) dan partikel tertahan pada membran, dengan demikian fluida umpan mengalir melalui tahanan membran dan tahanan penumpukan partikel pada permukaan membran (Mallack et al., 1997). Dengan demikian, pada aliran dead-end penyumbatan (clogging) dan pembentukan cake pada membran lebih cepat terjadi dibandingkan dengan sistem aliran cross-flow karena deposisi partikel pada permukaan membran akan tersapu (swept away) oleh kecepatan aliran umpan.

Ada dua parameter utama yang menentukan kinerja membran, yaitu :

a. selektivitas, dan

b. debit aliran persatuan luas (fluks).

Secara umum, fluks akan menentukan berapa banyak permeat yang dapat dihasilkan (kuantitas), sedangkan selektivitas berkaitan dengan kualitas permeat.

\section{Selektivitas}

Selektivitas suatu membran merupakan ukuran kemampuan suatu membran untuk menahan suatu spesi atau melewatkan suatu spesi tertentu. Selektivitas membran tergantung pada interaksi antar muka dengan spesi yang akan melewatinya. Secara umum selektifitas berhubungan dengan kualitas permeat yang dihasilkan disini ukuran pori permukaan membrane sangat berpengaruh.

\section{Debit permeat persatuan luas (Fluks)}

Fluks adalah jumlah volume permeat yang melewati satu satuan permukaan luas membran dengan waktu tertentu dengan adanya gaya dorong (driving force), 
dalam hal ini berupa tekanan. Secara umum fluks dapat dirumuskan sebagai berikut (Mulder, 1996) :

$$
\mathrm{J}=\frac{\mathrm{V}}{\text { A.t }}
$$

dimana :

$$
\begin{aligned}
& \mathrm{J}=\text { fluks }\left(\mathrm{L} / \mathrm{m}^{2} . \text { jam }\right) \\
& \mathrm{V}=\text { Volume permeat }(\text { Liter }) \\
& A=\text { Luas permukaan membran }\left(\mathrm{m}^{2}\right) \\
& \mathrm{t}=\text { waktu }(\text { jam })
\end{aligned}
$$

Masalah serius yang sering ditemui dalam proses ultrafiltrasi adalah kecenderungan terjadinya penurunan fluks sepanjang waktu pengoperasian akibat pengendapan atau pelekatan material di permukaan membran, yang dikenal dengan istilah fouling (Rautenbach, 1989). Fouling pada membran dapat didefinisikan sebagai deposisi (ir)reversible daripada partikel, koloid, emulsi, suspensi, makromolekul, garam, dan sebagainya yang tertahan pada permukaan, atau didalam membran (Mulder, 1996). Deposisi ini meliputi adsorpsi, penyumbatan pori, presipitasi (pengendapan) dan pembentukan cake. Deposisi partikel-partikel pada membran akan membentuk suatu lapisan baru yang harus dilalui oleh umpan sehingga fluks menjadi turun. Dari berbagai penyebab fouling, pembentukan cake pada permukaan merupakan faktor dominan dalam pembentukan reversible fouling, yang pada akhirnya menjadi faktor dominan dalam penurunan fluks.

Fenomena fouling sangat kompleks dan sukar untuk dijelaskan secara teoritis. Fouling dipengaruhi oleh parameter fisik dan kimiawi seperti konsentrasi, temperatur, $\mathrm{pH}$ kekuatan ionik, dan interaksi spesifik/ ikatan hidrogen atau interaksi dipol-dipol (Mulder, 1996). Pada fase akhir dari operasi, lapisan cake akan mengontrol fluks permeat. Model tahanan membran yang digunakan pada penelitian ini adalah model dimana tahanan cake mengendalikan fluks permeat dengan persamaan sebagai berikut (Malleviele, 1996):

$$
J^{2}=\frac{J o^{2}}{1+J o .^{2} k^{\prime} \cdot t}
$$

dimana :

$$
\begin{aligned}
J & =\text { Fluks }\left(\mathrm{L} / \mathrm{m}^{2} / \mathrm{jam}\right) \\
J o & =\text { Fluks awal }\left(\mathrm{L} / \mathrm{m}^{2} / \mathrm{jam}\right) \\
k^{\prime} & =\text { konstanta pembentukan cake } \\
t & =\text { waktu filtrasi (jam) }
\end{aligned}
$$


Linierisasi persamaan (2) diatas dapat digunakan untuk mencari nilai konstanta pembentukan cake, sebagai berikut :

$$
\frac{1}{J^{2}}=\frac{1}{J o .^{2}}+k^{\prime} \cdot t
$$

Harga k' dapat diperoleh dari kemiringan garis pada pemetaan linier $\left(1 / \mathrm{J}^{2}\right)$ terhadap waktu. Semakin besar nilai $\mathrm{k}$, menunjukkan semakin cepat laju pembentukan cake pada permukaan membran.

Untuk mengurangi penumpukan materi pada permukaan membran, ada dua cara yang dapat diambil, yaitu (Milisic,1996): (a). Menjaga partikel mengenai membran, atau (b) membersihkan membran tersebut. Untuk menjaga partikel mengenai membran, ada beberapa teknik yang digunakan seperti proses filtrasi, proses koagulasi dimana upaya-upaya tersebut lazim disebut sebagai pretreatment. Pada kasus limbah emulsi minyak-air ini pretreatment yang dilakukan ditujukan untuk memecahkan ikatan emulsi antara minyak dan air, sehingga diharapkan fasa minyak dan fasa air dapat terpisah. Untuk memecahkan emulsi minyak/air secara kimia, maka faktor penstabil harus terlebih dahulu dinetralisasi untuk membuka jalan bagi droplet teremulsi untuk bergabung (coalesce) (Byers J. D., 1994). Muatan elektrik dari droplet teremulsi dapat dinetralisasi dengan memberikan muatan berlawanan melalui penambahan bahan kimia pemecah emulsi. Karekteristik dielektrik dari air akan mengakibatkan droplet emulsi minyak memiliki muatan negatif, sehingga pemecah emulsi kationik atau bermuatan positif diperlukan untuk proses pemecahannya. Setelah emulsi minyak/air terpecahkan, secara ideal akan terbentuk dua lapisan yang sangat berbeda, sebuah lapisan air dan sebuah lapisan minyak. Dalam penelitian ini dilakukan pretreatment yang ditujukan untuk mengurangi beban membran, meningkatkan fluks dan diharapkan dapat memperpanjang waktu operasi (running time) dari membran.

Selain mengamati fouling, penelitian ini juga bertujuan melihat kemungkinan terjadinya deformasi struktur membran akibat tekanan yang diberikan kepadanya. Dengan SEM akan terlihat jelas struktur membran ultrafiltrasi secara keseluruhan, baik permukaan atas, potongan melintang, dan permukaan bawah. Selain itu struktur yang asimetris akan dapat diobservasi. Dari foto yang dihasilkan akan dapat pula diperkirakan ukuran pori, bentuk geometri pori, dan porositas permukaan

\section{Bahan dan Metodologi}

Penelitian dilakukan di Laboratorium Hidrolika dan Hidrologi Lingkungan Departemen Teknik Lingkungan ITB, dan Laboratorium Kualitas Air di 
Departemen yang sama. Analisa SEM dilakukan di Departemen Mesin ITB dan Pusat Penelitian Teknologi Mineral, Bandung. Secara garis besar percobaan yang dilakukan dalam penelitian ini dapat dibagi menjadi tiga bagian, yaitu:

- Bagian pertama penelitian, meliputi :

- penyiapan bahan untuk membuat membran

- pembuatan membran ultrafiltrasi

- penentuan fluks dan permeabilitas membran

- Analisa struktur membran dengan Scanning Elecron Miscroscope (SEM)

- Bagian kedua penelitian, meliputi :

- Analisa awal limbah cair emulsi minyak dari industri automotive

- Pretreatment limbah dengan penambahan Poly aluminium chloride dan asam sulfat

- Analisa kimia filtrat hasil pretreatment

- Bagian ketiga penelitian, meliputi :

- Operasi membran Ultrafiltrasi tahap I dengan membrane CA-!2, dan variasi umpan, yaitu umpan limbah tanpa pretreatment dan umpan limbah dengan pretreatment. Hal ini dilakukan untuk melihat fenomena fouling. Permeat dari proses tahap I ini kemudian digunakan sebagi umpan pada proses ultrafiltrasi tahap II yang menggunakan membrane CA-15.

- Analisa membran bersih dan yang telah digunakan dengan SEM

- Perhitungan konstanta pembentukan cake

- Operasi membran ultrafiltrasi tahap II dengan umpan permeat dari operasi membran ultrafiltrasi tahap I

Peralatan sel membran ultrafiltrasi terbuat dari bahan stainless steel dengan sistem aliran Cross flow, dan berbentuk bujursangkar, dengan sisi berukuran $11,2 \mathrm{~cm}$ dengan luas efektif $27,03 \mathrm{~cm}^{2}$. Detail dari set-up peralatan dapat dilihat dalam Notodarmojo et al. (2004).

\section{Membran yang digunakan}

Membran yang digunakan adalah membran sellulosa asetat CA-12 dan CA-15. Angka 12 dan 15 menunjukkan persentase berat sellulosa asetat dalam komposisi membran. Pembuatan membran dilakukan dengan cara inversi phasa dengan metode endap-rendam (Rautenbach, 1989). Pada pembuatan membran dengan bahan dasar selullosa asetat, serta aseton dan formamide sebagai solvent maka perhitungan komposisi didasarkan pada perbandingan berat selullosa asetat terhadap berat larutan polimer, dimana perbandingan aseton dengan formamide ditetapkan 1,5 (Rautenbach, 1989). Metoda pembuatan dan penggunaan membran tersebut telah dicoba dengan hasil yang baik (Zulkarnain, 
2000). Pemilihan membran yang digunakan adalah dengan menentukan terlebih dahulu permeabilitasnya terhadap air murni.

\section{Limbah \& pretreatment}

Limbah yang digunakan adalah limbah industri automotif dari proses pemotongan logam, yang berada di Bogor, Jawa Barat. Sebelum dilakukan pengolahan, terlebih dahulu dilakukan karakterisasi limbah, setelah itu dilakukan pretreatment pada limbah, yaitu dengan penambahan asam sulfat sampai $\mathrm{pH}$ optimum (7) dan penambahan Poly aluminium chloride ( $\mathrm{PACl})$, pada dosis optimum sebanyak 2,6 gr/L. Penetuan $\mathrm{pH}$ dan dosis optimum telah dilakukan sebelumnya. Umpan untuk operasi membran yaitu Limbah yang telah melalui proses pretreatment dan limbah asli tanpa pretreatment dengan sistem aliran cross-flow dua tahap. Tekanan yang digunakan, baik untuk tahap I maupun tahap II adalah 3,5 Bar konstan. Waktu operasi untuk penentuan fluks rata-rata adalah 90 menit, sedangkan untuk penentuan konstanta pembentukan cake digunakan waktu operasi 1200 menit (20 jam).

\section{SEM}

SEM merupakan metoda karakterisasi dan penelitian struktur pori pada membran mikrofiltrasi. Prinsip SEM secara garis besar, yaitu seberkas elektron dengan energi kinetic 1-25 kV ditembakkan pada sampel membran. Elektron yang ditembakkan disebut sebagai elektron primer (energi tinggi), dan yang dipantulkan adalah elektron sekunder (energi rendah). Elektron sekunder tidak dipantulkan tapi disebarkan oleh atom pada permukaan dan membentuk gambaran pada layar atau mikrograf (Mulder,1996). Analisa SEM dilakukan pada permukaan membran bersih dan membran yang telah digunakan. Selain itu, untuk melihat deformasi, analisa juga dilakukan pada potongan membran sebelum dan setelah digunakan.

\section{$3 \quad$ Hasil Penelitian dan Analisa}

Detail dari karakteristik limbah dan hasil olahan serta sebagian dari karakteristik hidrolik membrane seperti fluks dan permeabilitas disajikan dalam Notodarmojo et al. (2004). Dalam tulisan ini hanya disajikan data atau informasi yang dianggap penting dan tambahan informasi yang dianggap berhubungan dengan pembahasan.

\subsection{Karakteristik Limbah dan Membran}

\subsubsection{Analisa awal dari Limbah Emulsi Minyak Industri Automotif}

Karakteristik limbah awal dapat dilihat pada tabel 1, pH basa disebabkan adanya kandungan surfaktan dengan konsentrasi tinggi didalam limbah. 
Konsentrasi suspended solid yang tinggi terutama disebabkan adanya keberadaan mikroorganisme dan hasil dari pemotongan logam yang menyebabkan adanya partikel-partikel logam yang terkikis yang ikut ke dalam limbah, dan juga menyebabkan konduktivitas tinggi sebagai akibat dari logamlogam terlarut. Konsentrasi COD pada limbah tinggi disebabkan adanya kandungan minyak yang tinggi di dalam limbah, seperti yang ditampilkan pada tabel 1 kolom 2 Harga DO yang rendah menunjukkan bahwa kondisi air limbah cenderung anaerob. Selain itu terdapat pula kandungan logam berat yang merupakan limbah dari logam yang dipotong dalam proses fabrikasi.

\begin{tabular}{|l|l|l|l|}
\hline Parameter & $\begin{array}{l}\text { Limbah } \\
\text { Awal }\end{array}$ & $\begin{array}{l}\text { Setelah } \\
\text { pretreatment }\end{array}$ & Satuan \\
\hline Total Solid (TS) & 18929 & 2346 & $\mathrm{mg} / \mathrm{L}$ \\
Total Suspended Solid (TSS) & 15152 & 2282 & $\mathrm{mg} / \mathrm{L}$ \\
Total Dissolved Solid (TDS) & 2436 & 238 & $\mathrm{mg} / \mathrm{L}$ \\
COD & 63648 & 9300 & $\mathrm{mg} / \mathrm{L}$ \\
$\mathrm{DO}$ & 0,4 & 2,2 & $\mathrm{mg} / \mathrm{L}$ \\
$\mathrm{pH}$ & 8,84 & 5,8 & \\
Surfaktan & 702,3 & 500,84 & $\mathrm{mg} / \mathrm{L}$ \\
Konduktivitas & 3803 & 4020 & $\propto \mathrm{S}$ \\
Kekeruhan & 1241 & 154,8 & $\mathrm{Ntu}$ \\
Konsentrasi Minyak & 43650 & $\mathrm{n} . \mathrm{a}$ & $\mathrm{mg} / \mathrm{L}$ \\
Konsentrasi Logam : & & & \\
Cu & 0,809 & 0,038 & $\mathrm{mg} / \mathrm{L}$ \\
$\mathrm{Fe}$ & 4,459 & 1,2 & $\mathrm{mg} / \mathrm{L}$ \\
$\mathrm{Al}$ & 4,969 & 0,784 & $\mathrm{mg} / \mathrm{L}$ \\
$\mathrm{Sn}$ & 0,60 & 0,200 & $\mathrm{mg} / \mathrm{L}$ \\
$\mathrm{Pb}$ & 0,14 & 0,02 & $\mathrm{mg} / \mathrm{L}$ \\
$\mathrm{Zn}$ & 2,613 & 0,215 & $\mathrm{mg} / \mathrm{L}$ \\
$\mathrm{Ni}$ & 0,431 & 0,39 & $\mathrm{mg} / \mathrm{L}$ \\
$\mathrm{Cr}$ & 0,014 & 0,020 & $\mathrm{mg} / \mathrm{L}$ \\
$\mathrm{Co}$ & 0,04 & 0,02 & $\mathrm{mg} / \mathrm{L}$ \\
$\mathrm{V}$ & 0,008 & $\mathrm{n} . \mathrm{a}$ & $\mathrm{mg} / \mathrm{L}$ \\
\hline Catatan: n.a : tidak dilakukan analisa & \multicolumn{3}{|}{} \\
\hline
\end{tabular}

Tabel 1 Karakteristik limbah awal dan setelah pretreatment.

\subsubsection{Analisa Limbah Emulsi Minyak Setelah Proses Pretreatment}

Pretreatment dilakukan dengan dua tahap, yaitu dengan penambahan asam sulfat dan penambahan polimer PACl untuk destabilisasi emulsi minyak dalam limbah. Penentuan dosis optimum $\mathrm{PACl}$ pada dilakukan dengan cara penambahan dosis secara sistematis, untuk kondisi $\mathrm{pH}$ awal yang berbeda. Dengan cara tersebut didapatkan kondisi optimum untuk proses pretreatment yaitu pada $\mathrm{pH}$ awal limbah 7 dan dosis penambahan $\mathrm{PACl}$ 2,6 gr/L Kondisi optimum tersebut diambil pada kondisi $\mathrm{pH}$ dan dosis penambahan $\mathrm{PACl}$ yang 
memberikan konstribusi nilai COD yang terendah. Hasil analisa limbah setelah pretreatment disajikan dalam tabel 1 kolom 3, yang memberikan gambaran kualitas kimia dari filtrat hasil pretreatment yang akan menjadi umpan bagi operasi membrane.

\subsubsection{Fluks Membran}

Penentuan fluks dan permeabilitas dilakukan dengan melewatkan air murni pada membran yang diuji. Karena sifat permeabilitas membran yang relatif heterogen, maka pengujian membran dilakukan dengan beberapa kali ulangan (n run). Volume permeat yang keluar, diukur setiap selang waktu 5 menit. Data keseluruhan yang didapat diuji sifat homogenitasnya dengan metode plotting dari fluks rata-rata tiap membran dan tingkat kepercayaan $95 \%$ dengan bantuan software SPSS Versi 10. Dari pengujian data tersebut, maka hanya beberapa lembar membran yang memberikan homogenitas relatif sama. Fluks rata-rata dari membran tersebut dapat dilihat pada gambar 1 berikut.

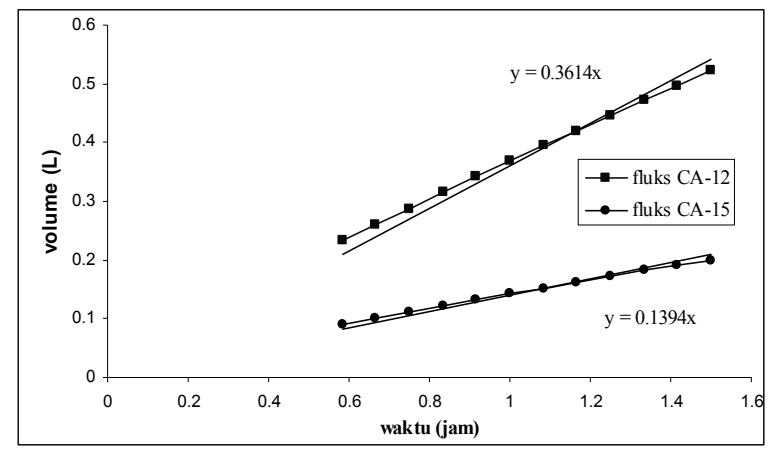

Gambar 1 Grafik hubungan volume permeat terhadap waktu

Analisa data yang disajikan dalam Gambar 1 memberikan suatu persamaan linier untuk masing-masing membran. Fluks operasi membran dinyatakan sebagai gradien grafik / luas sel membran efektif $\left(27,03 \mathrm{~cm}^{2}\right)$, sedangkan permeabilitas membran adalah fluks operasi/ tekanan operasi (3,5 Bar). Dari Gambar 1 kita dapatkan, bahwa membran CA-12 memiliki fluks 133,71 $\mathrm{L} / \mathrm{m}^{2}$.jam dengan permeabilitas $38,20 \mathrm{~L} / \mathrm{m}^{2}$.jam.Bar, sedangkan untuk membran CA-15 memiliki fluks $51,57 \mathrm{~L} / \mathrm{m}^{2}$.jam, dengan permeabilitas 14,74 $\mathrm{L} / \mathrm{m}^{2}$.jam.Bar. Membran ultrafiltrasi memiliki nilai permeabilitas antara $10-50$ $\mathrm{L} / \mathrm{m}^{2}$.jam.bar (Mulder, 1996). Sesuai dengan literatur, maka kedua jenis membran diatas termasuk dalam membran ultrafiltrasi. Lembaran membran yang relatif homogen tersebut selanjutnya digunakan untuk operasi proses membran terhadap limbah. 


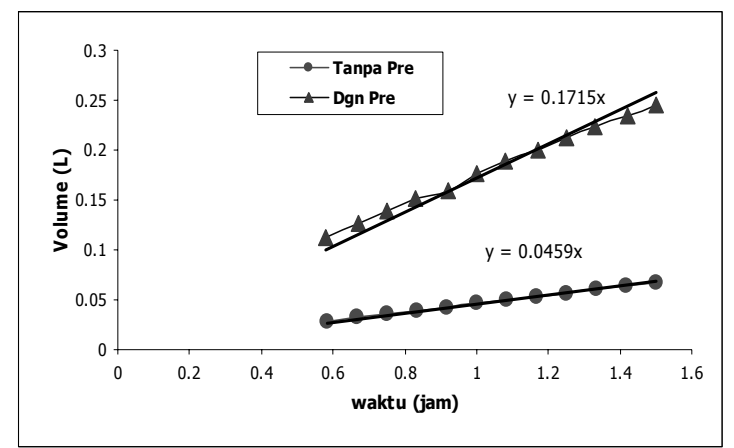

(a)

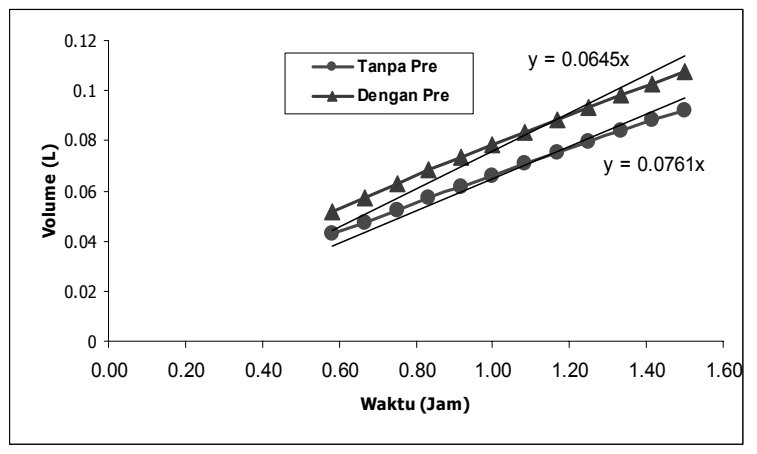

(b)

Gambar 2 Grafik hubungan volume limbah terhadap waktu pada membran CA-15: (a) membran CA-12; (b) membran CA-15

Gambar 2 memperlihatkan grafik volume limbah terhadap waktu operasi, untuk oparasi tahap I (CA-12) dan tahap II (CA-15). Pada operasi membran tahap satu yaitu membran CA-12, perbedaan umpan yang diolah akan memberikan hasil yang signifikan terhadap angka fluks. Fluks pada limbah tanpa pretreatment $17,03 \mathrm{~L} / \mathrm{m}^{2}$.jam, sedangkan pada limbah dengan pretreatment $59,05 \mathrm{~L} / \mathrm{m}^{2}$.jam. Perbedaan fluks yang signifikan terjadi karena pada limbah tanpa pretreatment, umpan membran merupakan limbah yang viscous dimana masih mengandung emulsi minyak, zat padat terlarut, dan kandungan surfaktan yang tinggi. Ketika zat terlarut tertahan oleh membran, zat tersebut akan terakumulasi dan membentuk suatu lapisan didekat permukaan membran yang disebut polarisasi konsentrasi. Polarisasi konsentrasi pada membran akan menyebabkan penurunan fluks membran secara terus menerus dan penurunan fluks ini merupakan fungsi dari waktu. Untuk penentuan fluks dari membran, digunakan data dari mulai 0,58 jam (35 menit) sampai 1,5 jam (90 menit), hal ini dilakukan karena penurunan nilai fluks pada selang waktu tiap 5 menit tidak terlalu besar.

Sedangkan pada operasi membran tahap dua yaitu membran CA-15, fluks pada ke dua umpan hampir sama yaitu $22,08 \mathrm{~L} / \mathrm{m}^{2}$.jam untuk limbah tanpa 
pretreatment dan $24,86 \mathrm{~L} / \mathrm{m}^{2}$.jam untuk limbah dengan pretreatment. Perbedaan fluks yang tidak signifikan disebabkan karena limbah telah mengalami proses pemisahan pada membran tahap satu, sehingga limbah yang akan diolah oleh operasi tahap dua secara parameter fisika telah memiliki karakteristik yang hampir sama. Penurunan fluks terjadi karena adanya materimateri yang tertahan dan tidak dapat lolos dari membran CA-15 seperti koloid berukuran kecil dan mikromolekul.

\subsection{Konstanta pembentukan cake ( $\left.k^{\prime}\right)$ dan fouling}

Setelah beberapa periode pengoperasian membran, maka membran akan mengalami deposisi partikel atau biasa disebut fouling, Fouling meliputi adsorpsi, penyumbatan pori, presipitasi (pengendapan) dan pembentukan cake yang akan menyebabkan terjadinya penurunan fluks permeat. Fluks dan fouling dipengaruhi salah satunya oleh konsentrasi umpan. Pendekatan fouling yang digunakan pada penelitian ini yaitu model sederhana dari model pembentukan cake dimana tahanan cake mengendalikan fluks permeat, yang dirumuskan pada persamaan 2 dan 3 pada bagian pendahuluan. Disini, laju pembentukan cake dinyatakan oleh konstanta laju pembentukan cake (k').

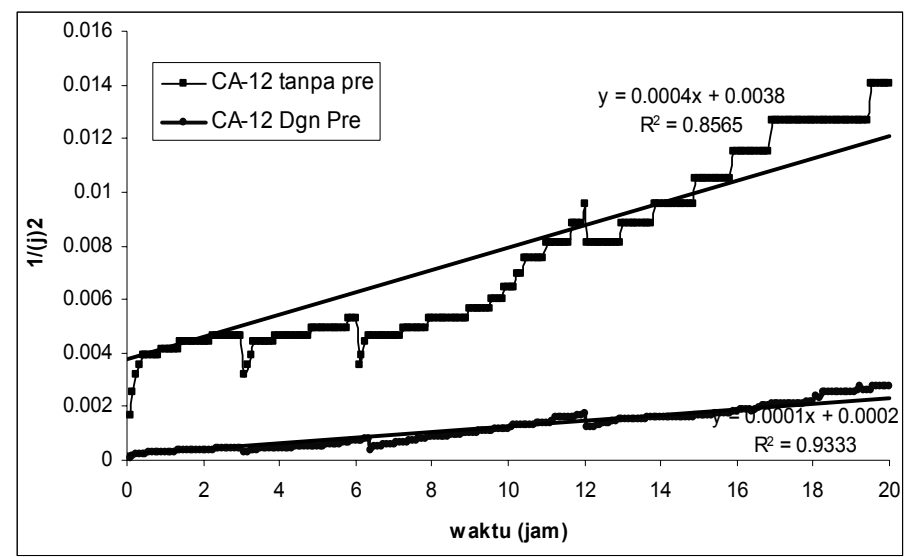

Gambar 3 Grafik penentuan konstanta pembentukan cake membran CA-12.

Pembentukan cake terjadi karena semakin banyaknya materi terdeposit yang dibawa umpan pada permukaan membran. Cake yang terbentuk semakin lama semakin tebal seiring dengan berjalannya waktu operasi. Perhitungan konstanta pembentukan cake dihitung dengan memplotkan $1 / \mathrm{J}^{2}\left(1 /\right.$ fluks $\left.^{2}\right)$ terhadap $\mathrm{t}$ (waktu operasi), yang disajikan dalam gambar 3 dan 4 . Konstanta pembentukan cake dihitung dari gradient yang terbentuk pada grafik. Nilai ini dapat dijadikan sebagai acuan dalam menilai terjadinya fouling karena pembentukan cake 
merupakan kendali bagi terjadinya fouling pada membran. Untuk memperoleh data pengamatan yang memadai, operasi membrane diperpanjang hingga 20 jam. Grafik dan hasil perhitungan k' yang merupakan kemiringan garis $1 / \mathrm{J}^{2}$ vs. $\mathrm{t}$, dapat dilihat pada gambar dan hasilnya disajikan dalam tabel 2 berikut.

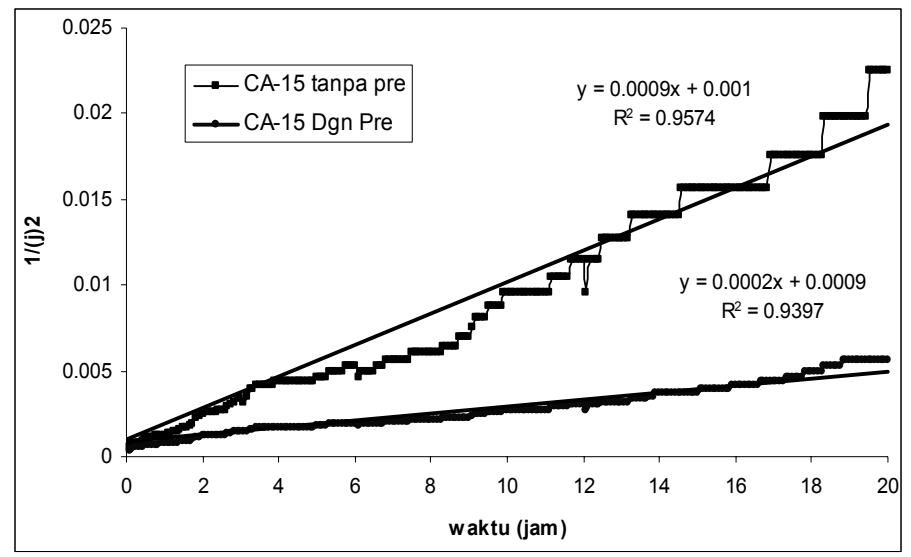

Gambar 4 Grafik penentuan konstanta pembentukan cake membran CA-15

\begin{tabular}{|c|c|c|c|}
\hline Membran & Fluks & Fluks akhir & Konstanta \\
\hline Tahap I (CA-12) & $\left(L / m^{2} . j a m\right)$ & (L/m².jam) & pembentukan Cake \\
\hline Tanpa Pretreatment & 16,22 & 9,21 & 0,0004 \\
\hline Dengan Pretreatment & 70,71 & 21,32 & 0,0001 \\
\hline $\begin{array}{c}\text { Membran } \\
\text { Tahap II (CA-15) } \\
\end{array}$ & $\begin{array}{c}\text { Fluks } \\
(\mathrm{L} / \mathrm{m} 2 . j \mathrm{am})\end{array}$ & $\begin{array}{l}\text { Fluks akhir } \\
\text { (L/m2.jam) }\end{array}$ & $\begin{array}{c}\text { Konstanta } \\
\text { pembentukan Cake }\end{array}$ \\
\hline Tanpa Pretreatment & 31,63 & 7,25 & 0,0009 \\
\hline Dengan Pretreatment & 33,33 & 14,29 & 0,0002 \\
\hline
\end{tabular}

Tabel 2 Hasil perhitungan konstanta pembentukan cake membran

Dari tabel diatas, terlihat bahwa konstanta pembentukan cake (k') pada umpan limbah tanpa pretreatment untuk kedua operasi membran memiliki nilai yang lebih tinggi (rata-rata 4 kali) dibandingkan dengan umpan limbah dengan pretreatment. Belum diperoleh data nilai k' dari literature untuk limbah yang sama sebagai pembanding. Perbedaan nilai konstanta pembentukan cake yang signifikan terjadi karena pada limbah tanpa pretreatment, umpan membran merupakan limbah yang viscous dimana masih mengandung emulsi minyak, zat padat terlarut, dan kandungan surfaktan yang tinggi. Ketika zat terlarut tertahan oleh membran, zat tersebut akan terakumulasi dan membentuk suatu lapisan didekat permukaan membran yang disebut polarisasi konsentrasi. Polarisasi konsentrasi pada membran dapat menyebabkan penurunan fluks membran secara terus menerus dan penurunan fluks ini merupakan fungsi dari waktu. 


\subsection{Struktur Membran}

Analisa struktur membran dilakukan untuk melihat ukuran pori dan ketebalan membran yang digunakan. Untuk melihat, mengukur pori membran dan ketebalan membran digunakan analisa SEM (Scanning Elektron Miscroscope). Selain itu dari foto SEM diharapkan dapat terlihat apakah ada deformasi membrane setelah digunakan atau tidak.

Dari hasil SEM (gambar 5) diketahui ketebalan membran adalah berkisar 7-8 $\mu \mathrm{m}$ dan ukuran pori yang dapat teridentifikasi adalah antara $100-300 \mathrm{~nm}$. Karakteristik struktur membran ultrafiltrasi adalah memiliki ukuran pori antara $1-200 \mathrm{~nm}$ dengan ketebalan membran antara $1-20 \mu \mathrm{m}$ (Mulder,1996). Dengan demikian, berdasarkan strukturnya, membrane tersebut dapat dikategorikan sebagai membrane ultra filtrasi.

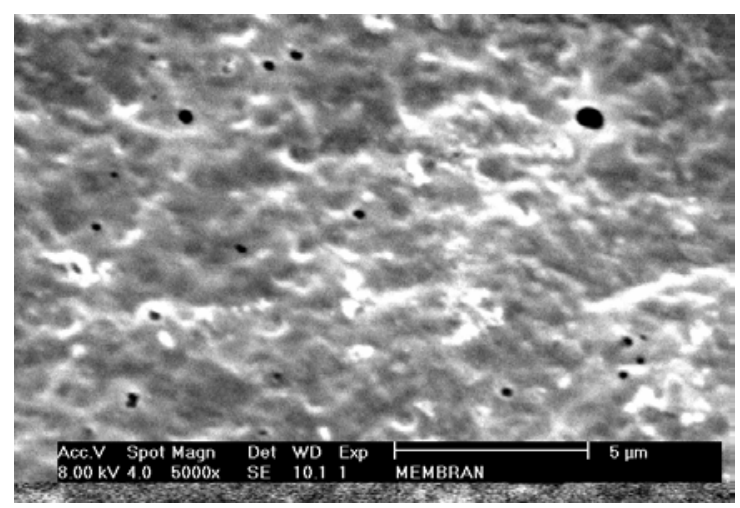

(a)

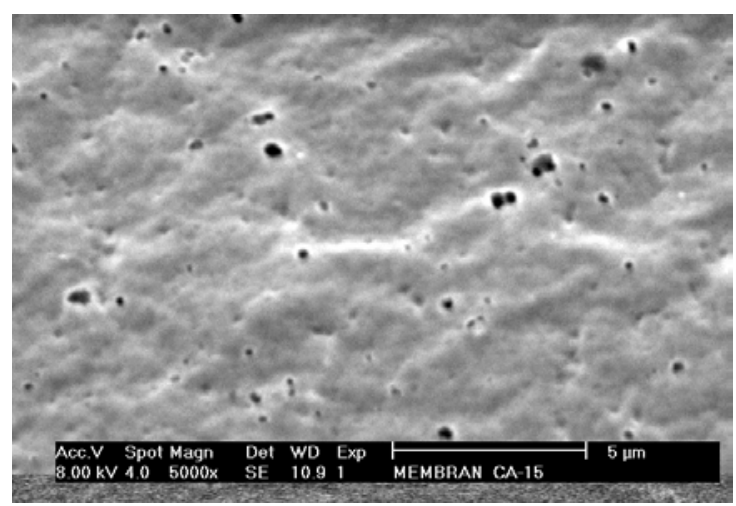

(b)

Gambar 5 Hasil SEM pada permukaan datar dari (a) membran CA-12 (b) membran CA-15

Fouling pada umumnya terjadi pada membran berpori seperti pada membran ultrafiltrasi. Tahanan filter yang tertahan pada membran tidak dapat 
terhindarkan. Visualisasi fouling pada penelitian ini ditunjukkan dengan foto SEM seperti yang terlihat pada gambar 6 berikut.

Dari Gambar 6 (a) terlihat struktur membran bersih dalam arti belum digunakan. Analisa struktur pori pada permukaan penampang membran dengan SEM menunjukkan bahwa membrane tersebut merupakan membran asimetrik, yaitu membran yang mempunyai dua lapisan dengan lapisan yang sangat tipis pada bagian atas disebut dengan kulit yang berfungsi sebagai membran utama dan bagian bawahnya berupa lapisan yang lebih tebal dan berpori jauh lebih besar yang berfungsi sebagai penyangga. Membran asimetrik merupakan membrane yang tersusun oleh beberapa lapisan. Struktur membran asimetrik terdiri atas lapisan yang sangat padat dan lapisan berpori sebagai penyangga (spinger). Pada membran asimetrik permeasi terjadi pada lapisan padat yang memiliki tahanan perpindahan massa yang besar. Lapisan pendukung dibuat berpori sehingga tidak mempunyai tahanan perpindahan massa yang besar.

Dari Gambar 6 (b) terlihat bahwa fouling tidak hanya terjadi pada bagian permukaan atas atau lapisan luar membran saja yang membentuk cake, tetapi juga terjadi pada bagian spinger/ lapisan dalam membran. Pengotor yang masuk kedalam lapisan dalam tersebut terjadi akibat adanya tekanan yang diberikan selama proses operasi membran, tekanan akan mendorong deposisi partikel pada permukaan membran/ lapisan atas untuk masuk ke dalam lapisan dalam membran.

Selain itu, dalam gambar 6 (b) terlihat juga deformasi dari struktur dalam (spinger) membrane, yang diduga sebagai akibat tekanan (driving force) yang diterima oleh membrane. Lapisan spinger yang terdiri dari lapisan tipis tegak lurus terhadap permukaan membrane tampaknya tidak cukup kuat untuk menahan tekanan kerja sebesar 3,5 bar yang digunakan dalam penelitian ini. Adanya deformasi ini memperkuat dugaan Mahmud (2001) yang menduga adanya deformasi pada lapisan spinger dari membrane ultra filtrasi yang digunakan. Deformasi ini tampaknya reversible, hal ini terlihat dari hasil pengulangan penggunaan membrane yang menunjukkan hasil yang relative sama. Mahmud (2001) melaporkan bahwa dari segi hidrolis terindikasi adanya deformasi membrane akibat driving force, sampai pada waktu tertentu, dan selanjutnya deformasi tersebut tidak terjadi lagi. Hal ini dibuktikan melalui proses filtrasi menggunakan aqudest, dimana pada awal proses terjadi penurunan fluks, yang selanjutnya setelah beberapa saat fluks menjadi konstan. Walaupun demikian, penelitian khusus mengenai pengaruh deformasi terhadap penurunan kinerja membrane perlu dipelajari lebih lanjut.

Deposisi pengotor dalam lapisan dalam/spinger ini diduga menyebabkan linearisasi $1 / \mathrm{J}^{2}$ vs $t$, yang digunakan untuk mencari nilai $\mathrm{k}^{\prime}$ tidak berhasil 
sepenuhnya, walaupun nilai koefisien determinasi yang ditunjukkan cukup baik (nilai $\mathrm{R}^{2}$ paling rendah 0,8555 ). Plot data hasil pengamatan menunjukan nonlinearitas yaitu semakin meningkatnya nilai $1 / \mathrm{J}^{2}$ terhadap waktu. Peningkatan nilai yang tidak linier tersebut menunjukkan bahwa laju penurunan fluks semakin meningkat dengan cepat. Hal ini menunjukkan bahwa ada faktor lain selain pembentukan cake pada permukaan membran. Diduga faktor penyebab tersebut adalah deposisi pengotor dalam spinger.

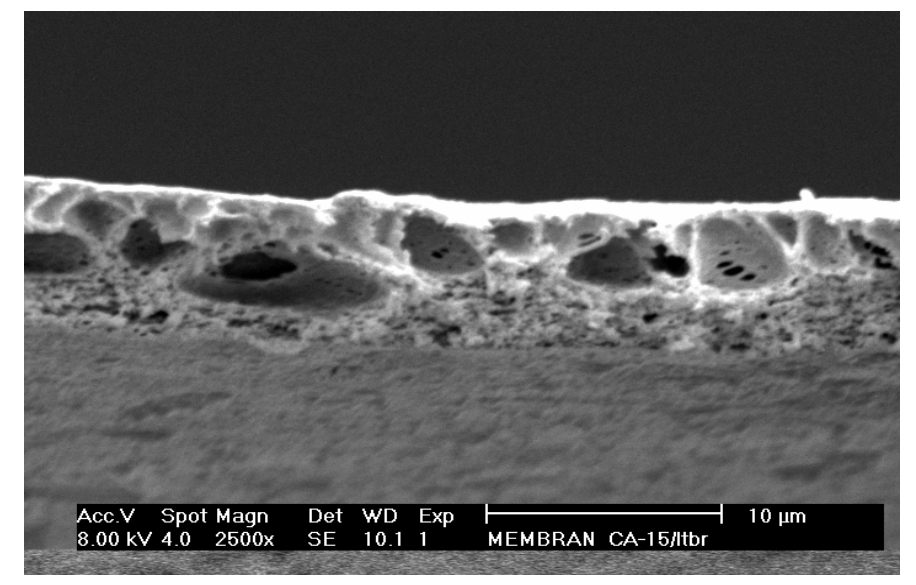

(a)

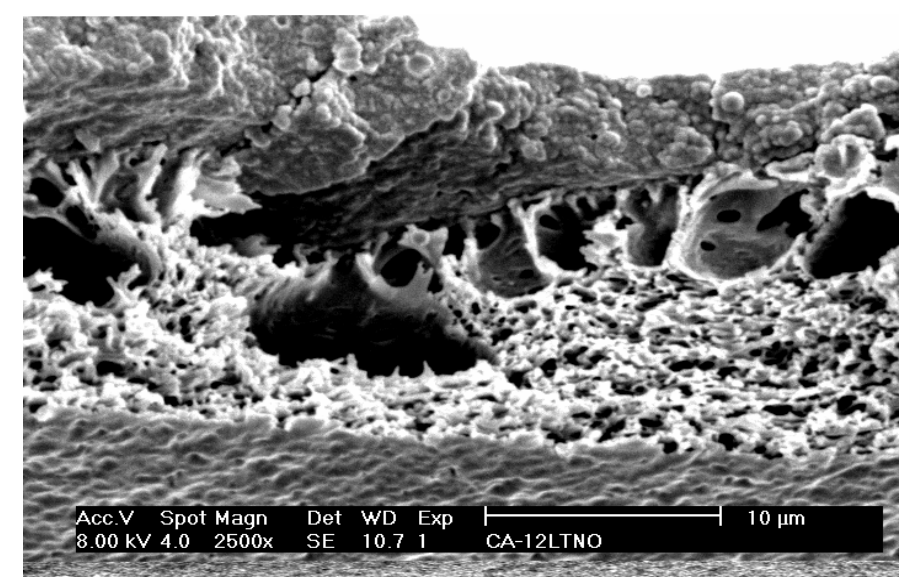

(b)

Gambar 6 Foto Tampak melintang SEM membrane sebelum dan sesudah digunakan: (a) Foto SEM membran bersih (tampak melintang); (b) Foto SEM membran yang telah terkotori (tampak melintang).

Selanjutnya, dalam Gambar 7 disajikan foto SEM dari membran CA-12 dengan variasi umpan limbah asli tanpa pretreatment dan umpan limbah hasil pretreatment. Dari Gambar 7 terlihat membran dengan permukaan mendatar yang telah terkotori (fouling), sedangkan sebagai perbandingan membran bersih 
tampak mendatar dapat dilihat pada gambar 5. Pada gambar 5 terlihat membran dengan bulatan-bulatan pori membran, tetapi pada gambar 7 , pori membran telah tertutupi oleh pengotor. Dari gambar 7 juga terlihat pengotor pada membran dengan umpan limbah tanpa pretreatment (a), tampak ukuran pengotornya lebih besar dibandingkan umpan limbah dengan pretreatment (b). Hal tersebut terjadi karena pada umpan limbah tanpa pretreatment, umpan limbah masih sangat viscous dan masih banyak terdapat droplets minyak dan partikel-pertikel berukuran besar (makromolekul). Sedangkan, pada umpan limbah dengan pretreatment, umpan limbah sudah mengalami proses pemisahan awal dengan sebagian droplet minyak dan makromolekul, sehingga yang tertahan pada membran merupakan partikel-partikel kecil (mikromolekul).

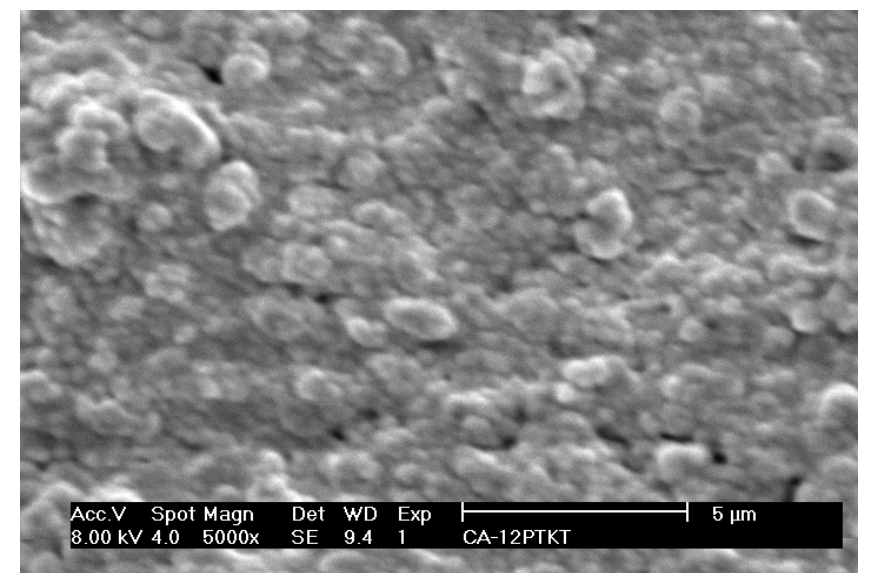

(a)

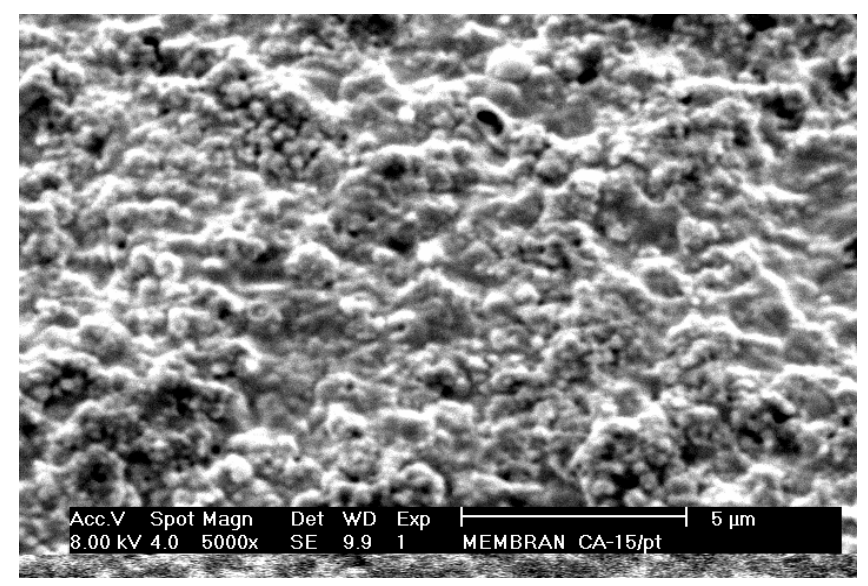

(b)

Gambar 7 Membran yang telah terkotori (tampak mendatar) dari membran CA-12: (a) umpan limbah tanpa pretreatment; (b) umpan limbah dengan pretreatment. 


\section{$4 \quad$ Kesimpulan}

Dari hasil penelitian dan pembahasan dapat ditarik beberapa kesimpulan sebagai berikut:

1. Umpan limbah dengan pretreatment memberikan hasil fluks yang lebih baik dari umpan limbah tanpa pretreatment pada operasi membran tahap I, dimana fluks limbah tanpa pretreatment $17,03 \mathrm{~L} / \mathrm{m}^{2} . j a m$, sedangkan pada limbah dengan pretreatment $59,05 \mathrm{~L} / \mathrm{m}^{2} . j a m$.

2. Pada operasi membran tahap II (membran CA-15) fluks yang dihasilkan dari kedua umpan hampir sama yaitu fluks limbah tanpa pretreatment $22,08 \mathrm{~L} / \mathrm{m}^{2}$.jam dan fluks limbah dengan pretreatment $24,86 \mathrm{~L} / \mathrm{m}^{2}$.jam.

3. Keunggulan proses membran menggunakan umpan limbah dengan pretreatment disamping dapat meningkatkan fluks permeat, juga dapat menurunkan konstanta pembentukan cake yang berdampak pada meningkatnya waktu operasi membran.

4. Hasil analisa SEM menunjukkan adanya deposisi kontaminan dalam lapisan dalam (spinger membrane). Selain itu juga terindikasi adanya deformasi struktur spinger akibat driving force yang digunakan dalam operasi filtrasi.

5. Perlu dipertimbangkan adanya deposisi dalam lapisan dalam membrane dalam perhitungan nilai k', atau perlu dicari formula baru untuk menghitung nilai k' yang menyertakan faktor deposisi yang terjadi dalam spinger membrane.

\section{Ucapan Terima Kasih}

Penulis ingin mengucapkan terima kasih sebesar-besarnya kepada ibu Dr. Cinthya L. Radiman atas saran beliau terutama dalam penyempurnaan teknik pembuatan membran dan bantuan material. Selain itu, sebagian penelitian ini telah dibiayai oleh Program Riset Unggulan Terpadu (RUT IX), untuk itu penulis mengucapkan terima kasih kepada Kantor Menteri Negara Riset dan Teknologi (KMNRT) dan semua pihak terkait atas bantuannya.

\section{Daftar Pustaka}

1. Bennett, E. O., The Disposal of Metal Cutting Fluids, Lub. Eng (1973).

2. $\quad$ Byers, P. J., Metalworking Fluids, Marcel Dekker Inc (1994).

3. Kim, B. R., Matz, M. J. \& Lapari, F., Treatment of Metal-Cutting Fluid Wastewater using an Anaerobic GAC Fluidized-bed Reactor, Journal Water Pollutant (1989).

4. Mahmud, Aplikasi membrane Ultra Filtrasi sellulosa asetat untuk pengolahan air gambut, Thesis Magister, Departemen Teknik Lingkungan ITB (2001). 
5. Mallack, H. M. \& Anderson, G. K., Cross-flow Microfiltration with Dynamic Membrans, Journal Water Research, Vol. 31, Elsevier Science Ltd (1997).

6. Mulder, M., Basic Principles of Membran Technology, Kluwer Academic Publisher, Netherlands (1996).

7. Malleviele, J., Water Treatment Membran Process, McGraw-Hill (1996).

8. Milisic,V., Antifouling Techniques in Crossflow Microfiltration, Journal of Membran Science, Elsevier, Amsterdam (1986).

9. Notodarmojo, Suprihanto, Dini Mayasanthy \& Teuku Zulkarnain, Pengolahan Limbah Cair Emulsi Minyak Dengan Proses Membran Ultrafiltrasi Dua-tahap Aliran Cross-flow, Proceeding ITB, vol. 36 A no.1 (2004).

10. Peter, E., Water Treatment Membran Process, McGraw-Hill, Washington (1996).

11. Rautenbach R., \& Albert R., Membran Process, John Wiley \& Sons Ltd., New York (1989).

12. Zulkarnain, T., Pengolahan limbah cair emulsi minyak menggunakan membrane ultrafiltrasi sellulosa asetat, Thesis Magister, Departemen Teknik Lingkungan ITB (2000). 